\title{
TINJAUAN PSIKOLOGIS TERHADAP HUKUMAN MATI
}

\author{
Pujiastuti Handayani \\ Hakim pada Pengadilan Negeri Cilacap \\ Korespondensi: handayani_pujiastuti@yahoo.com
}

\begin{abstract}
Abstrak
Tindak pidana mutilasi merupakan kejahatan terhadap tubuh dalam bentuk pemotongan bagian-bagian tubuh tertentu dari korban. Persoalan terkait tindak pidana mutilasi yaitu penerapan sanksi pidana terhadap pelaku berupa hukuman mati. Tulisan ini akan menguraikan penerapan hukuman mati terhadap tindak pidana mutilasi yang ditinjau dari perspektif psikologis, hak asasi manusia, maupun agama.
\end{abstract}

Kata-kata Kunci: Tindak Pidana; Mutilasi; Hukuman Mati.

\begin{abstract}
The criminal act of mutilation is a crime against the body in the form of cutting certain body parts of the victim. One of the issues related to mutilation as a crime is the application of death penalty to the perpetrators. This paper describes the application of the death penalty for the perpetrator of the crime of mutilation from a psychological, human rights, and religiousperspectives.
\end{abstract}

Key Words: Criminal Act; Mutilation; Death Penalty. 


\section{PENDAHULUAN}

Indonesia sebagai negara yang menjunjung tinggi supremasi hukum memberikan perlindungan hukum kepada seluruh warganya dengan meletakkan kepastian hukum sebagai asas dalam penegakan hukum, bahwa penjatuhan hukum harus setimpal dengan kesalahannya. ${ }^{1} \mathrm{Hal}$ itu pula yang menyebabkan sistem hukum Indonesia yang menganut civil law menggunakan Kitab Undang-Undang Hukum Pidana (KUHP) yang berisi tentang berbagai bentuk tindak pidana sebagai Law in Book yang di dalamnya termasuk mengatur tentang pidana mati sebagai salah satu jenis hukuman pokok. ${ }^{2}$

Menurut KUHP, ada sembilan kejahatan yang diancam dengan pidana mati yaitu: Makar dengan maksud membunuh Presiden dan Wakil Presiden (Pasal 104 KUHP); Melakukan hubungan dengan negara asing sehingga terjadi perang (Pasal 111 ayat (2) KUHP); Pengkhianatan memberitahukan kepada musuh di waktu perang (Pasal 124 ayat (3) KUHP); Menghasut dan memudahkan terjadinya huru-hara (Pasal 124 KUHP); Pembunuhan berencana terhadap kepala negara sahabat (Pasal 140 ayat (3) KUHP); Pembunuhan berencana (Pasal 340 KUHP); Pencurian dengan kekerasan secara bersekutu mengakibatkan luka berat atau mati (Pasal 365 ayat (4) KUHP); Pembajakan di laut mengakibatkan kematian (Pasal 444 KUHP); Kejahatan penerbangan dan sarana penerbangan (Pasal $149 \mathrm{~K}$ ayat (2) dan pasal 149 O ayat (2) KUHP). ${ }^{3}$ Selain itu di luar KUHP, dikenal pula beberapa macam kejahatan yang dapat dijatuhi hukuman mati, antara lain: UU No. 12/Drt/1951 tentang Senjata Api, Amunisi atau Bahan Peledak; UU No. 7/ Drt/1955) tentang Tindak Pidana Ekonomi; UU No. 11/Drt/1963) tentang pemberantasan kegiatan subversi; UU No. 22 Tahun 1997 dan UU No. 5 Tahun 1997 tentang tindak pidana Narkotika dan Psikotropika; UU No. 20 tahun 2001 tentang Tindak Pidana Korupsi. ${ }^{4}$

Dalam tata hukum Indonesia, pidana mati merupakan bagian dari proses pemidanaan sebagaimana yang

Istilah kepastian hukum dalam hukum pidana Indonesia mengacu kepada kodifikasi hukum (Code Napoleon 1804). Dengan menggunakan istilah itu, di luar kodifikasi tidak diakui adanya aturan hukum, sehingga hukum yang diterapkan hakim hanya apa yang tercantum dalam kitab undang-undang itu saja. Jadi undang-undanglah yang dipandang sebagai satu-satunya sumber hukum. Pandangan ini bertumpu pada anggapan bahwa hukum itu berasal dari kehendak mereka yang mempunyai kekuasaan tertinggi dalam negara, ialah berasal dari kehendak pembentuk undang-undang. Penciptaan hukum di luar pembentukan undangundang tidak diakui. Sudarto, Kapita Selekta Hukum (Alumni 1986) 53-54.

2 Pidana mati adalah salah satu bentuk pidana yang paling tua, setua umat manusia. Pidana mati juga merupakan bentuk pidana yang paling menarik dikaji oleh para ahli, karena memiliki nilai kontradiksi atau pertentangan antara yang setuju dan yang tidak setuju. Oleh karena itu jika membicarakan tentang pidana mati, maka kemudian yang akan dikemukakan adalah tentang sejarah pidana mati itu sendiri, pelaksanaan pidana mati, pro dan kontra terhadap pidana mati, tindak pidana tindak pidana yang dapat dikenakan pidana mati. Mohammad Taufik Makarao, Pembaharuan Hukum Pidana Indonesia (Kreasi Wacana 2005) 206-207.

$3 \quad$ Bambang Waluyo, Pidana dan Pemidanaan (Sinar Grafika 2000) 19.

4 Djoko Prakoso dan Nurwachid, Studi tentang Pendapat-pendapat Mengenai Efektivitas Pidana Mati di Indonesia Dewasa Ini (Ghalia Indonesia 1999) 27-28. 
dirumuskan oleh BPHN tentang rencana KUHP Nasional. ${ }^{5}$ Secara eksplisit disebutkan, bahwa pemidanaan bersifat pencegahan terhadap berulangnya suatu perbuatan dan bimbingan untuk tidak melakukan perbuatan serupa. Pada dasarnya pemidanaan tidak dimaksudkan untuk menimbulkan penderitaan yang dapat merendahkan martabat manusia, namun dalam realitanya hukuman mati yang diberlakukan di Indonesia bertentangan dengan prinsip dasar dimaksud.

\section{PEMBAHASAN}

\section{Persepsi tentang Hukuman Mati}

Hukuman mati merupakan hukuman paling berat. Hukuman ini masih diberlakukan di Indonesia meskipun Belanda sebagai negara asal dari KUHP telah menghapuskan hukuman mati sejak tahun 1870, serta negara lainnya seperti Jerman, Italia, Portugal, Austria, Swiss dan negaranegara Skandinavia. Namun demikian, ada pula negara yang telah menghapuskan, tetapi kemudian mengadakan lagi, misalnya Rusia. ${ }^{6}$

Sejak zaman dahulu, pidana mati untuk kejahatan pembunuhan dan kejahatan-kejahatan lain yang sama beratnya telah dikenakan hampir di setiap negara di dunia berdasarkan atas pembalasan terhadap perbuatan yang sangat kejam dari pelaku. Tujuan menjatuhkan dan menjalankan pidana mati selalu diarahkan kepada khalayak ramai agar takut melakukan perbuatanperbuatan kejam yang dapat mengakibatkan mereka di pidana mati.

Pidana mati dapat dikatakan sebagai salah satu jenis pidana tertua dan paling kontroversial di dunia. Pidana mati adalah satu-satunya pidana yang tepat dan adil bagi kejahatan-kejahatan berat yang tidak dapat diampuni. Oleh karena itu, paling tidak, pidana mati dapat dianggap mempunyai efek menakutkan yang diperlukan untuk melindungi masyarakat. Selain itu bila si penjahat tidak dieksekusi, maka ia akan selalu dapat melarikan diri dari penjara atau jika pada suatu waktu ia dibebaskan, maka ia akan dapat mengulangi kembali kejahatannya.

Dalam penerapan hukuman mati ini, baik di Indonesia maupun negaranegara di dunia, masih banyak ditanggapi dengan pendapat pro dan kontra. Kelompok yang pro terhadap pemberlakuan hukuman mati ini mengemukakan berbagai alasan, antara lain sebagai berikut:

a. Pidana mati menjamin bahwa penjahat tidak akan berkutik lagi, masyarakat tidak akan diganggu lagi oleh orang tersebut sebab mayatnya telah dikuburkan sehingga tidak

5 Tujuan pemidanaan di Indonesia adalah: 1) untuk mencegah dilakukannya perbuatan pidana, demi pengayoman negara, masyarakat dan penduduk; 2) untuk membimbing agar terpidana insyaf dan menjadi anggota masyarakat yang berbudi baik dan berguna; 3) untuk menghilangkan noda-noda yang diakibatkan oleh perbuatan pidana. J.E.Sahetapy, Suatu Studi Khusus Mengenai Ancaman Pidana Mati terhadap Pembunuhan Berencana (Rajawali 1982) 184.

6 Andi Hamzah dan Sumagelipu, Pidana Mati di Indonesia di Masa Lalu, Kini dan di Masa Depan (Ghalia Indonesia 1983) 12. 
perlu lagi takut kepada terpidana (deaarde bedekt het lejk en vanden veroordeelde is niets meer te vreezen).

b. Pidana mati merupakan suatu alat represi yang kuat bagi pemerintah, terutama dalam memerintah di Hindia Belanda.

c. Dengan alat represi yang kuat ini, maka kepentingan masyarakat dapat dijamin sehingga suasana ketentraman dan ketertiban di masyarakat dapat tercapai.

d. Dengan adanya alat represi yang kuat ini sekaligus berfungsi sebagai prevensi umum, sehingga diharapkan calon penjahat akan mengurungkan niatnya untuk melakukan kejahatan.

e. Terutama dengan pelaksanaan eksekusi di depan umum, diharapkan timbulnya rasa takut yang lebih besar untuk melakukan kejahatan.

f. Dengan dijatuhkan serta dilaksanakan pidana mati itu, diharapkan adanya seleksi buatan, sehingga masyarakat dibersihkan dari unsur-unsur jahat dan buruk, dan diharapkan akan tercipta wargawarga yang baik saja. ${ }^{7}$

Kelompok yang kontra terhadap pemberlakuan hukuman mati, mengemukakan alasan-alasan sebagai berikut:

a. Sifatnya yang tidak mungkin dapat ditarik kembali. Apabila pidana mati telah dilaksanakan maka tidak mungkin untuk diubah atau diperbaiki kembali.

b. Hakim adalah manusia biasa yang tidak luput dari kesalahan. Bila pidana mati telah dilaksanakan apalah artinya jika kemudian ternyata terbukti terpidana tidak berdosa, padahal orangnya sudah dihukum mati.

c. Pidana mati bertentangan dengan nilai perikemanusiaan.

d. Bahwa pidana mati bertentangan dengan nilai moral dan etika.

e. Mengingat akan tujuan pemidanaan, maka pidana mati itu: (a) Bagi orang yang sudah dijatuhi pidana mati itu tidak dapat lagi kembali ke tengahtengah masyarakat untuk memperbaiki kelakuannya, dengan demikian tujuan pemidanaan untuk memperbaiki diri penjahat tidak akan tercapai; (b) Pelaksanaan pidana mati itu biasanya tidak dilaksanakan di hadapan umum, sehingga dengan demikian tidak mungkin disaksikan oleh orang banyak. Hal ini menyebabkan tujuan menciptakan efek jera tidak akan tercapai.

f. Pada umumnya terhadap orang yang akan dijatuhi hukuman mati, akan menimbulkan perasaan belas kasihan terhadap orang lain dan masyarakat (peristiwa isteri Rosenberg yang dijatuhi hukuman mati di atas kursi listrik di Amerika Serikat). ${ }^{8}$ 
Walaupun penerapan hukuman mati dalam praktik sering menimbulkan kontroversi antara yang pro dan kontra, namun kenyataannya secara yuridis formal pidana mati itu memang dibenarkan. Hal ini dapat dibuktikan oleh beberapa pasal yang ada di dalam KUHP dan di luar KUHP tetap mencantumkan adanya pidana mati.

Menurut Pasal 11 KUHP, pidana mati dilakukan oleh algojo di tempat penggantungan dengan menggunakan sebuah jerat di leher terhukum, dan mengikatkan jerat itu pada tiang penggantungan dan menjatuhkan papan tempat si terhukum itu berdiri. Sejak Jepang menduduki Indonesia, Belanda mengeluarkan Staatsblad 1945 No. 123 bahwa pidana mati dilakukan dengan tembak mati. Lalu diperkuat dengan UU No. 2/PNPS/1964 yang ditetapkan menjadi UU No. 5 Tahun 1969 yang menyatakan bahwa pidana mati dilakukan dengan menembak mati terpidana. Dalam pelaksanaannya, pidana mati dilakukan dengan dihadiri oleh Jaksa (Kepala Kejaksaan Negeri) sebagai eksekutor dan secara teknis dilaksanakan oleh Polisi. ${ }^{10}$ Dari ketentuan tersebut, pidana mati dimaksudkan untuk mewujudkan tujuan hukum yaitu kedamaian (peace), keadilan (justice), kemanfaatan (utility) dan kepastian (certainty).
Indonesia telah beberapa kali memiliki Rancangan KUHP Nasional. Dalam pembahasan naskah Rancangan KUHP Nasional tahun 2002 sebagai ius constituendum, terdapat hal-hal yang perlu diperhatikan antara lain:

a. Pidana mati dilaksanakan oleh regu penembak dengan menembak terpidana sampai mati.

b. Pelaksanaan pidana mati tidak dilakukan di depan umum.

c. Pidana mati tidak dapat dijatuhkan kepada anak di bawah umur 18 tahun.

d. Pelaksanaan pidana mati terhadap wanita hamil atau orang yang sakit jiwa, ditunda sampai wanita tersebut melahirkan atau orang yang sakit jiwa tersebut sembuh.

e. Pidana mati baru dapat dilaksanakan setelah ada persetujuan presiden atau penolakan grasi oleh Presiden.

f. Pelaksanaan pidana mati dapat ditunda dengan masa percobaan selama sepuluh tahun, jika: ${ }^{11}$ (a) Reaksi masyarakat terhadap terpidana tidak terlalu besar; (b) Terpidana menunjukkan rasa menyesal dan ada harapan untuk memperbaiki diri; (c) Kedudukan terpidana dalam penyertaan tindak pidana tidak terlalu penting; (d) Ada alasan yang meringankan; (e) Jika terpidana selama masa percobaan menunjukkan sikap dan perbuatan

\footnotetext{
8 Hermin Hediati Kuswadji, Perkembangan Macam-macam Pidana dalam Kerangka Pembangunan Hukum Pidana (PT. Citra Aditya Bakti 1995) 22.

10 Ediwarman, Hukuman Mati dan Masalahnya (Sinar Indonesia Baru 2004) 13.

11 Direktorat Jenderal Peraturan Perundang-undangan Departemen Hukum dan HAM Tahun 2002 , 'Rancangan Undang-undang Republik Indonesia tentang Kitab Undang-undang Hukum Pidana'.
} 
yang terpuji, maka pidana mati dapat diubah menjadi pidana seumur hidup atau pidana penjara paling lama 20 tahun dengan keputusan dari Menteri Kehakiman.

g. Jika terpidana selama masa percobaan tidak menunjukkan sikap dan perbuatan yang terpuji, serta tidak ada harapan untuk memperbaiki diri, maka pidana mati dapat dilaksanakan atas perintah Jaksa Agung.

h. Jika setelah permohonan grasi ditolak maka pelaksanaan pidana mati tidak dilaksanakan selama sepuluh tahun bukan karena terpidana melarikan diri, maka pidana mati tersebut dapat diubah menjadi pidana seumur hidup dengan keputusan dari Menteri Kehakiman.

\section{Tujuan Penghukuman}

Berdasarkan penjelasan di atas mengenai pengaturan pidana mati, maka jelas berbeda antara Rancangan KUHP Nasional tahun 2002 dengan KUHP yang masih berlaku saat ini, seperti adanya pengaturan masa percobaan 10 tahun sebagai penundaan pelaksanaan pidana mati, pidana mati tersebut dapat diubah menjadi pidana seumur hidup atau menjadi 20 tahun penjara dengan keputusan dari Menteri Kehakiman, dan ada beberapa kejahatan dalam KUHP yang masih berlaku saat ini diancam dengan pidana mati, sedangkan pada Rancangan KUHP
Nasional tahun 2002 tidak diancam dengan pidana mati.

Bila dilihat dari hukum positif, pelaksanaan pidana mati memang sangat mencemaskan, karena setelah pidana mati dilaksanakan tidak ada lagi upaya yang terbuka untuk memperbaikinya. Hal ini sungguh dapat dipahami karena hukum positif tidak mempertimbangkan penghisaban kembali yang akan terjadi di hari akhirat nanti. Hukum positif hanya mengatur kehidupan duniawi (mundane). Sedangkan hukum agama, selain mengatur kehidupan duniawi juga berkaitan dengan kehidupan ukhrowi (transedental). ${ }^{12}$

Demikian halnya apabila pidana mati ditinjau dari sudut pandang hak asasi manusia, maka hal ini bertolak belakang dengan Undang-Undang Dasar Negara Republik Indonesia Tahun 1945 (UUD NRI 1945) yang telah diamandemen, dan Undang-Undang Nomor 39 Tahun 1999 tentang Hak Asasi Manusia (UU No. 39 Tahun 1999). ${ }^{13}$ Dalam UUD NRI 1945, hak asasi manusia telah dituangkan dalam batang tubuh yang dijabarkan dalam Pasal 27, Pasal 28 A s/d 28 J, Pasal 29, 30 dan 34. Ketentuan UUD NRI 1945 ini dikaitkan dengan UU No. 39 Tahun 1999 menyatakan bahwa setiap orang berhak hidup di dalam tatanan masyarakat dan kenegaraan yang damai, aman dan tenteram yang menghormati, melindungi dan

\footnotetext{
12 Todung Mulya Lubis dan Alexander Lay, Kontroversi Hukuman Mati-Perbedaan Pendapat Hakim Konstitusi (Kompas 2009) 1.
} 
melaksanakan sepenuhnya hak asasi manusia, dan kewajiban dasar manusia, sebagaimana diatur dalam undangundang ini. ${ }^{14}$

Pasal 28 A UUD NRI 1945 secara tegas menyatakan bahwa "setiap orang berhak untuk hidup serta berhak mempertahankan hidup dan kehidupannya." Inilah hak asasi yang non-derogable, tidak dapat dikurangi dalam keadaan apapun. Sesuai dengan asas konstitusional, legalitas produk hukum positif yang masih mempertahankan pidana mati seharusnya disesuaikan dengan konstitusi. Ini harus dilakukan agar tidak bertentangan dengan asas ketatanegaraan, karena legalitas hukuman mati sebagai produk hukum yang lebih rendah bertentangan dengan produk hukum yang lebih tinggi. ${ }^{15}$

Pasal 28 I ayat (1) UUD NRI 1945 menyatakan bahwa hak hidup adalah hak asasi yang tidak dapat dikurangi dalam keadaan apapun, oleh karena itu pidana mati yang tujuan utamanya dengan sengaja mencabut hak hidup seseorang bertentangan dengan dengan UUD NRI 1945. ${ }^{16}$ Menyikapi pernyataan ini Mahmud Mulyadi berpendapat bahwa setiap manusia tidak berhak menentukan hidup atau matinya seseorang, karena yang berhak untuk menentukan hidup atau matinya seseorang adalah Allah SWT. Jadi dapat ditegaskan bahwa hanya Allah SWT yang berhak untuk menentukan hidup atau matinya seseorang. Akan tetapi, cara untuk hidup atau matinya seseorang bukan Allah SWT yang menentukan, terpulang kepada manusia itu sendiri dalam menentukan cara kehidupannya dan cara matinya dalam kehidupan di dunia ini. Hal ini dilandaskan pada argumen bahwa dalam agama Islam, seorang muslim diwajibkan mempercayai Rukum Iman yang salah satunya adalah percaya kepada Ghadho dan Gadhar (biasa dikenal dalam masyarakat sebagai takdir yang baik dan takdir yang buruk). ${ }^{17}$

\section{Perspektif Psikologi dalam Penerapan Hukuman Mati}

Akhir-akhir ini, sebagian dari kita mungkin telah mendengar banyak berita tentang protes dan kritik dari berbagai elemen masyarakat tentang pelaksanaan hukuman mati. Sebagian besar dari mereka yang memprotes adanya hukuman mati tersebut beranggapan bahwa hukuman mati merupakan suatu praktik pelanggaran HAM, yaitu hak untuk hidup. Mereka beranggapan bahwa dengan menghukum mati seseorang maka secara jelas kita telah merampas hak untuk hidup orang terhukum tersebut.

13 Ediwarman, 'Pidana Mati Ditinjau dari Sudut Pandang Hak Asasi Manusia' Makalah Fakultas Hukum Universitas Sumatera Utara, Medan, tanpa tahun).

14 Pasal 35 UU No. 39 Tahun 1999.

15 Indriyanto Seno Adji, 'Hukuman Mati Beratmosfer HAM' (Tempo Agustus 2004) 110.

16 Todung Mulya dan Alexander Lay, Loc.Cit.

17 Mahmud Mulyadi, Criminal Policy - Pendekatan Integral Penal Policy dan Non Penal Policy dalam Penanggulangan Kejahatan Kekerasan (Pustaka Bangsa Press, 2008) 8. 
Akan tetapi, dilihat dari sisi hukum dan keadilan, maka hukuman mati merupakan sebuah praktik hukum yang adil. Pendapat yang sering diajukan sebagai pembelaan atas pelaksanaan hukuman mati adalah bahwa orang terhukum tersebut pantas dihukum mati. Jadi dapat kita lihat disini ada dua sisi yang bertentangan. Satu sisi adalah hak asasi manusia, sedangkan sisi lainnya adalah keadilan.

Sebagaimana ilmu-ilmu yang lain, psikologi bertujuan untuk mengerti suatu gejala atau fenomena. Untuk itu, psikologi memerlukan teori. Dalam menyusun teori diperlukan data atau fakta dari pengalaman, namun tidak semua data dapat digunakan untuk penyusunan teori, melainkan hanya data yang memenuhi syarat yang diperoleh dari suatu eksperimen atau dengan kata lain dari suatu pengamatan dalam suatu situasi di mana faktorfaktor yang berpengaruh dikendalikan oleh peneliti.

Definisi dari teori itu sendiri adalah, serangkaian hipotesis atau proposisi yang saling berhubungan tentang suatu gejala atau sejumlah gejala. Definisi ini menggambarkan tentang apa yang dimaksud dengan teori. Dalam ilmu psikologi dikenal adanya dua bagian besar teori mengenai kejiwaan yaitu:

a. Teori Molar, yaitu teori tentang individu sebagai keseluruhan, misalnya teori tentang tingkah laku individu dalam proses kelompok; b. Teori Molekular, yaitu teori tentang fungsi-fungsi syaraf dalam tubuh suatu organisme.

Berkaitan dengan dua aliran besar teori dalam ilmu psikologi tersebut, memerlukan penderivasian teori oleh karena itu para sarjana psikologi menyusun berbagai teori pendukung dengan objek kajian kejiwaan individu, yaitu sebagai berikut:

a. Stimulus Response Theory; Teori ini mendasarkan pada pernyataan bahwa tingkah laku manusia berkembang berdasarkan rangsang dan tingkah laku balas yaitu konsepkonsep dasar untuk menerangkan gejala tingkah laku yang dapat diukur dan didefinisikan secara nyata.

b. Teori Belajar Sosial dan Tiruan; Menurut teori ini perkembangan kondisi jiwa individu dipengaruhi oleh empat prinsip dalam belajar yaitu, dorongan (drive), isyarat (cue), tingkah laku balas (response), dan ganjaran (reward), yang mana saling memiliki hubungan kausalitas.

c. Teori Proses Pengganti; Menyatakan bahwa tingkah laku manusia yang bersifat tiruan merupakan suatu bentuk asosiasi suatu rangsang dengan rangsang lainnya, yang memperkuat tingkah laku balas tetapi bukan syarat yang penting dalam proses belajar individu, sehingga dikategorikan sebagai proses pengganti.

Berdasarkan teori-teori diatas maka dapat dipahami bahwa perkembangan 
jiwa individu dipengaruhi oleh faktor interaksi belajar secara sosial dari lingkungan sekitarnya di mana efek internal individu memiliki kecenderungan untuk mengalami perubahan.

Selanjutnya beberapa proses psikologi diterangkan oleh beberapa teori-teori yang mendasari tahapan perkembangan kejiwaan individu dalam suatu kelompok masyarakat, sebagai berikut :

a. Teori Kognitif, umumnya menyatakan bahwa perkembangan jiwa individu dipengaruhi oleh persepsi yang merupakan refresentasi fenomenal tentang objek distal sebagai hasil pengorganisasian objek distal itu sendiri;

b. Teori Disonansi Kognitif, menyatkan bahwa dalam perkembangan jiwa individu dimungkinkan terjadi hubungan yang tidak koheren yang menimbulkan kejanggalan yang mendorong perubahan tingkah laku individu.

Dalam perkembangan kondisi kejiwaan manusia melalui dua proses belajar, yaitu proses belajar secara fisik dan belajar secara psikis, dimana seseorang mempelajari perannya dan peran orang lain dalam kontak sosial. Selanjutnya, individu tersebut akan menyesuaikan tingkah lakunya sesuai dengan peran sosial yang dipelajarinya itu. Perkembangan kejiwaan individu erat dengan adanya proses tingkah laku tiruan (imitation) melaui tiga mekanisme yaitu : a. Tingkah laku sama terjadi apabila dua orang bertingkah laku balas sama terhadap isyarat yang sama sehingga tidak ditemukan suatu faktor pembeda yang menjadi ciri khas di antara keduanya;

b. Tingkah laku tergantung timbul dalam hubungan antara dua pihak diamana salah satu pihak memilki kelebihan dari pihak yang satu

c. Tingkah laku salinan dipengaruhi oleh ganjaran dan hukuman terhadap kuat atau lemahnya tingkah laku tiruan.

Dalam proses peniruan tingkah laku terdapat hubungan timbal balik antara satu pihak yang berfungsi sebagai superior atau yang menjadi model percontohan dan satu pihak sebagai inferior yang melakukan proses imitasi.

Erik Erikson dalam bukunya Childhood and Society menjelaskan tahapan perkembangan karakter kejiwaan setiap individu berdasarkan prinsip epigenetik yang menyatakan bahwa kepribadian kita berkembang melalui delapan tahap. Satu tahap ditentukan oleh keberhasilan atau ketidakberhasilan tahap sebelumnya. Setiap tahapan memiliki tugas-tugas perkembangan sendiri-sendiri yang pada hakikatnya bersifat psikososial, yang berpengaruh terhadap individu dan masyarakat.

Selanjutnya mengenai fase-fase perkembangan jiwa manusia oleh Alfred Adler dengan memperluas pendapat Erik Erikson dibagi kedalam delapan tahapan yaitu: 
a. Tahap pertama oral sensory stage, terjadi pada usia nol sampai dengan satu tahun. Tugas yang harus dijalani pada tahap ini adalah mengembangkan kepercayaan tanpa harus menekan kemampuan untuk tidak dipercaya;

b. Tahap kedua anal muscular stage, masa balita yang berlangsung mulai dari usia delapan belas bulan sampai usia tiga atau empat tahun, tugas yang harus diselesaikan pada tahap ini adalah kemandirian sekaligus memperkecil perasaan malu dan ragu-ragu;

c. Tahap ketiga genital locomotor stage, disebut juga tahap bermain, berlangsung antara usia tiga sampai dengan enam tahun, pada tahap ini seorang individu belajar mempunyai gagasan tanpa banyak melakukan kesalahan;

d. Tahap keempat latency stage, yang terjadi pada usia sekolah dasar antara umur enam sampai dengan dua belas tahun, kondisi jiwa pada masa ini adalah individu berusaha mengembangkan kemampuan kerja keras dan menghindari perasaan rendah diri;

e. Tahap kelima teenagers stage,yang dimulai pada saat masa puber dan berakhir pada usia delapan belas tahun, kondisi jiwa individu pada tahap ini adalah adanya pencapaian identitas pribadi (ego identity) dan menghindari peran ganda (role confusion);

f. Tahap keenam young adulthood, yaitu usia antara delapan belas sampai tiga puluh tahun. Usia di tahap dewasa ini lebih cair dibandingkan tahap kanak-kanak, dan setiap orang berbeda satu sama lain. Kondisi kejiwaan pada tahap ini adalah adanya kedekatan dengan orang lain (intimacy);

g. Tahap ketujuh middle adulthood, dalam tahap ini tercakup periode dimana individu terlibat langsung dengan kehadiran anak-anak.

Sejarah hukum pidana pada masa lampau mengungkapkan adanya sikap dan pendapat seolah-olah pidana mati merupakan obat yang paling mujarab terhadap kejahatan-kejahatan berat ataupun terhadap kejahatan-kejahatan lain. Dalam pada itu bukan saja pada masa lampau, sekarang pun masih ada yang melihat pidana mati sebagai obat yang paling mujarab untuk kejahatan.

Menurut Saparinah Sadli, kejahatan merupakan salah satu bentuk dari “perilaku yang menyimpang”, yang selalu ada dan melekat pada tiap bentuk masyarakat, tidak ada masyarakat yang yang sepi dari kejahatan. Perilaku menyimpang itu merupakan suatu ancaman yang nyata atau ancaman terhadap norma-norma sosial yang mendasari kehidupan atau keteraturan sosial, yang dapat menimbulkan ketegangan individual maupun ketegangan-ketegangan social dan merupakan ancaman riil atau potensial bagi berlangsungnya ketertiban sosial. Dengan adanya perilaku yang menyimpang dalam masyarakat, ketertiban dan kesejahteraan Negara tidak dapat terwujud. ${ }^{20}$ 
Dengan pembahasan mendalam terhadap masalah ini secara akademik, diharapkan dapat menambah informasi ilmiah yang dimiliki oleh penulis perihal perlu atau tidaknya (pro dan kontra) pidana mati diterapkan di Indonesia dengan melihat apakah ia dapat memberikan pengaruh agar tujuan pemidanaan untuk menanggulangi kejahatan dapat tercapai. Lebih lanjut tulisan ini bermaksud memberikan penjelasan yang bersifat teoritis mengenai tinjauan psikologis peranan sanksi yang dalam hal ini adalah pidana mati, sehingga dapat memberikan pandangan dan informasi yang akurat atau setidak-tidaknya menjadi sebuah pemikiran dari penulis dalam rangka memperkaya dan memperluas khasanah ilmu pengetahuan.

\section{PENUTUP}

Banyak aspek yang harus disertakan dalam melakukan penanggulangan kejahatan, salah satunya adalah fungsi hukum. Fungsi hukum ditempatkan sebagai suatu acuan atau pedoman yang dapat berinteraksi dengan acuan atau pedoman yang lain. Hal ini dikarenakan penanggulangan kejahatan tidak cukup melalui sarana hukum saja, tetapi juga dengan usaha-usaha yang bersifat kebijakan sosial seperti membuka lapangan kerja, perbaikan moral, perbaikan pendidikan masyarakat serta perbaikan lingkungan.
Pada dasarnya, tujuan penghukuman pidana atas kejahatan tidak hanya untuk menakut-nakuti masyarakat agar jangan melakukan kejahatan. Dengan adanya pengungkapan fakta dan data berdasarkan penelitian sosiokriminologis maka harapan yang ditimbulkan pada masa lampau dengan adanya berbagai bentuk dan sifat pidana mati yang kejam agar kejahatankejahatan yang berat dapat dibasmi.

\section{DAFTAR BACAAN}

Ediwarman, Hukuman Mati dan Masalahnya (Sinar Indonesia Baru 2004).

Hamzah, Andi, dan Sumagelipu, Pidana Mati di Indonesia di Masa Lalu, Kini dan di Masa Depan (Ghalia Indonesia 1983).

Kuswadji, Hermin Hediati, Perkembangan Macam-macam Pidana dalam Kerangka Pembangunan Hukum Pidana (PT. Citra Aditya Bakti 1995).

Lubis, Todung Mulya, dan Alexander Lay, Kontroversi Hukuman Mati Perbedaan Pendapat Hakim Konstitusi (Kompas, 2009).

20 Saparinah Sadli dalam Barda Nawawi Arief dan Muladi, Teori-Teori dan Kebijakan Pidana (Alumni 1998) 148. 
Prakoso, Djoko, dan Nurwachid, Studi tentang Pendapat-pendapat Mengenai Efektivitas Pidana Mati di Indonesia Dewasa Ini (Ghalia Indonesia 1999).

Makarao, Mohammad Taufik, Pembaharuan Hukum Pidana Indonesia (Kreasi Wacana 2005).

Mulyadi, Mahmud, Criminal Policy Pendekatan Integral Penal Policy dan Non Penal Policy dalam Penanggulangan Kejahatan Kekerasan (Pustaka Bangsa Press 2008).

Sahetapy, J.E., Suatu Studi Khusus Mengenai Ancaman Pidana Mati terhadap Pembunuhan Berencana (Rajawali 1982).

Arief, Barda Nawawi, dan Muladi, TeoriTeori dan Kebijakan Pidana (Alumni 1998).

Seno Adji, Indriyanto, Hukuman Mati Beratmosfer HAM, (Jakarta: Tempo, Edisi 23-29 Agustus 2004).

Sudarto, Kapita Selekta Hukum (Alumni 1986).

Waluyo, Bambang, Pidana dan Pemidanaan (Sinar Grafika 2000).

\section{Lain-lain}

Direktorat Jenderal Peraturan Perundang-undangan Departemen Hukum dan HAM Tahun 2002 'Rancangan Undang-undang Republik Indonesia tentang Kitab Undang-undang Hukum Pidana'.
Ediwarman, 'Pidana Mati Ditinjau dari Sudut Pandang Hak Asasi Manusia' (Makalah Fakultas Hukum Universitas Sumatera Utara, Medan, tanpa tahun). 